\title{
ARTICLE
}

Special Issue: Sexual Violence and Criminal Justice in the 21 st Century

Section I: Defining Sexual Autonomy and the Consent Paradigm

\section{The Human Right to Sexual Autonomy}

\author{
Dana-Sophia Valentiner \\ Faculty of Economics and Social Sciences, Helmut Schmidt University, Hamburg, Germany \\ Corresponding author: Dana.Valentiner@hsu-hh.de
}

(Received 17 June 2021; accepted 17 June 2021)

\begin{abstract}
During the $20^{\text {th }}$ century, society's view on sexualities has undergone a severe paradigm shift. While moving away from ideas of decency and bawdiness to evaluate legitimate sexuality, concepts of autonomy and consent gained importance. This transformation is also challenging the law. ${ }^{1}$ With the broad acceptance of various forms of sexual behavior and sexual orientation, legal regulation based on morality and ethics is outdated. Recent debates on law and sexualities focus on sexual autonomy and its conditions. This is shown especially by the legal debate on sexual violence and criminal law. ${ }^{2}$ But the right to sexual autonomy does not only require adequate protection against sexual violence. As a human right, it obliges State Parties to Human Rights Treaties such as the European Convention on Human Rights and the Convention on the Elimination of Discrimination against Women to respect, protect, and fulfill sexual autonomy. This includes the guarantee of freedom from sexual violence, coercion and discrimination, as well as control over one's own body and over the involvement in sexual interactions with others. In order to ensure the different components of sexual autonomy, sexual education and reliable access to information and medical services are necessary. This paper presents an approach concerning the multifaceted dimensions of sexual autonomy through a human rights lens.
\end{abstract}

Keywords: Sexual autonomy; human rights; sexual rights; consent; gender equality; European Convention on Human Rights; CEDAW; Yogyakarta Principles

\section{A. Rethinking Sexuality: From Decency to Autonomy and Consent}

In the last 70 years, there have been tremendous transformations regarding sexuality. Social movements fought for the right of people to live their sexuality free of traditional moral concepts. Medical-technological progress is marking a new age of self-determined decisions in the area of sexuality by introducing the contraceptive pill and new reproductive technologies. These developments call for theorizing sexual rights in new terms of autonomy and sexual consent.

The author thanks Emily Laing, Hannah Kölle and Valérie V. Suhr for their thoughtful review of an earlier draft of this paper.

${ }^{1}$ See generally Ulrike Lembke, Regulierungen Des Intimen: Sexualität Und Recht Im Modernen StaAt (2017).

${ }^{2}$ See Ralf Kölbel, "Progressive" Criminalization? A Sociological and Criminological Analysis Baased on the German "No means No" Model, 22 German L.J. (2021), in this special issue; Linnea Wegerstad, Responsibility and Voluntariness: On the Scope of Criminalization after the 2018 Swedish Rape Law Reform, 22 GERMAN L.J. (2021), in this special issue. 


\section{Social, Political, and Technological Changes}

With the so-called sexual revolution in the 1960s, the way we think about and deal with sexualities has undergone a fundamental social change. Of course, there has always been social and legal regulation of sexual behavior. Moreover, violations of sexual self-determination through sexualized violence and rape are no new phenomena. However, for a long time, sexualities were barely discussed due to traditional moral concepts and taboos. The topic remained hidden from social and legal discourse. This has changed with the sexual revolution. Social movements-in particular second wave feminism-declared "the personal is political." Their criticism was directed against social structures and conditions of power which led to the suppression of sexuality. Above all, this included the separation between public and private spheres and the description of sexuality as a private matter. ${ }^{3}$ Social movements of the 1960s and 1970s-especially the student's and women's movements - adopted the critique on the public/private divide and turned it against patriarchal structures of the state as well as against bourgeois sexual morality and the idealization of the married, heterosexual nuclear family. ${ }^{4}$

The arising movements affect society as a whole. Social sciences research shows that the evaluation of sexualities has undergone a paradigmatic change. ${ }^{5}$ The traditional ideas of decency and bawdiness have been replaced over time. Autonomy and sexual consent have emerged as new standards. Consensual sexual relations-desired by both, or more, partners-are seen as a new ideal. Medical and technological progress in the area of reproduction, the rise of oral contraceptives, and a new capture of sexuality as a market for self-optimization are further developments that influence thinking about sexuality.

The field of sexuality is not only socially and politically contested, but research on sexuality has also evolved and changed significantly. In the $19^{\text {th }}$ and early $20^{\text {th }}$ century, research on sexualities was dominated by scholars of medicine, biology, and psychoanalysis. ${ }^{6}$ In the mid $-20^{\text {th }}$ century, sociological sexology acquired a different perspective, concentrating on the social dimension of sexual behavior and the social meaning of sexuality. ${ }^{7}$ The empirical studies demonstrated the range of variation in human sexual behavior, questioned the binarity of homosexuality and heterosexuality, and emphasized the social and cultural regulation of sexuality. Sexology research during the late 1960s and early 1970s led to further perception about the social shaping of sexuality. Today's multidisciplinary sexual sciences disentangle themselves from essentialism and naturalism. They deal with sexualities as social phenomena. They are concerned with systems of sexuality-with interaction ${ }^{8}$ and communication ${ }^{9}$ among persons.

Furthermore, sexuality studies have included feminist analyses of gender, sexuality and power, as well as Foucault's discourse analysis. They have found the attempts to define sexualities to fall somewhere between the construction of common and hidden knowledge. This is what Catharine A. MacKinnon called "it is as if sexuality comes from the stork." ${ }^{10}$ Hidden knowledge implies that

\footnotetext{
${ }^{3}$ See Jean Bethke Elshtain, Public Man, Private Woman: Women in Social and Political Thought (1981); Carole Pateman, The Sexual Contract (1988); Joan B. Landes, Feminism, The Public and the Private (1998).

${ }^{4}$ Shulamith Firestone, The Dialectic of Sex (1970).

${ }^{5}$ Anthony Giddens, The Transformation of Intimacy (1992); Gunter Schmidt, Das neue Der Die Das 8 (4th ed., 2014); Volkmar Sigusch, Kultureller Wandel der Sexualität, in SeXuelle Störungen Und Ihre BeHANDlung 16, 26 (Volkmar Sigusch ed., 1996).

${ }^{6}$ Sigmund Freud, Drei Abhandlungen zur SeXualtheorie und verwandte Schriften 1856-1939 (1961); Sándor

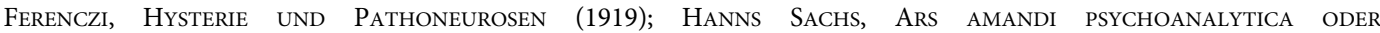

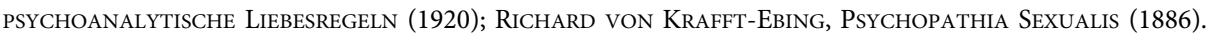

${ }^{7}$ Alfred C. Kinsey, Wardell B. Pomeroy \& Clyde E. Martin, Sexual Behavior in the Human Male (1948); Alfred C. Kinsey, Wardell B. Pomeroy, Clyde E. Martin \& Paul H. Gebhard, Sexual Behavior in the Human Female (1953); William H. Masters \& Virginia E. Johnson, Human Sexual Response (1966). See also Margaret Mead, Male and FEMALE (1949).

${ }^{8}$ Rüdiger Lautmann, Soziologie der Sexualität 203 (2002).

${ }^{9}$ Sven Lewandowski, SeXualität in Den Zeiten funkTiOnaler DifFerenZierung (2004).

${ }^{10}$ See Catharine A. Mackinnon, Toward a Feminist Theory of the State 130 (1989).
} 
something is not worthy of further discussion because of its private character ("That's none of our business."). Common knowledge is assumed to be generally known ("We all know what is meant."), so further discussion becomes obsolete. The "mystification that shrouds the subject"11 takes place in a vortex of morality, which forms a linguistic culture within media, law, and politics, with rules about when, with whom, and in which context which concrete matters can be discussed.

In law, taboos affect jurisprudence as well as legislation; they are normatively codified in laws and decisions. A striking example for the construction of common and hidden knowledge in the legal discussion about sexualities is the concurring opinion of United States Supreme Court Justice Potter Stewart in the 1964 case Jacobellis v. Ohio. ${ }^{12}$ The Court dealt with the prohibition of the possession and display of obscene pornography ("obscenity"). Stewart described the line between permissible and obscene pornography with the words "I know it when I see it." His statement illustrates the challenge of grasping sexual behavior-in this case pornographic pictures-as a legal point of reference. At the same time, the statement marks the subjectivity of judicial decision-making, which is particularly relevant in-formerly-tabooed, moralized issues. ${ }^{13}$

So far, legislation and jurisprudence have also hardly developed any usable concepts of sexuality and sexual autonomy. Social changes have affected the law in some areas. For example, legislation on homosexuality was liberalized in many countries, marital rape became punishable (in 1997 in Germany), and gender equality was implemented in many legal areas. In other areas, however, there is evidently a strong reluctance to conceptualize the right to sexual autonomy, its conditions and implications. A current example can be found in German sexual criminal law. ${ }^{14}$ The "definition" of "sexual acts" in Section 184h (1) No. 1 German Penal Code (StGB) states that the law only covers acts of "some relevance." 15 There is no detailed information about what is meant by a sexual act. Additionally, the Prostitute Protection Act of 2016 does not define "sexual services" but refers to the German Penal Code stating the term is clarified there. ${ }^{16}$ This is just another way of saying "I know it when I see it." This example shows the need to update legal concepts to ensure sexual autonomy through the ongoing paradigm shift.

\section{Gendered Sexualities}

Sexualities are deeply gendered. This can clearly be seen in advertising strategies relying on "sex sells" principles. The commercialization of sexuality has an obvious gender dimension. It can be described in terms of a "commodity model," meaning that sexuality becomes a commodity for women to have and for men to desire. ${ }^{17}$ This model also explains popular gendered attributions - such as degrading women who have sex with more than one person as sluts (-shaming). ${ }^{18}$ It shows how social practices of gender and sexuality can reinforce each other. The sexualization of the (female) body is accompanied by a very specific expectation of sexual behavior. John H. Gagnon and William Simon presented the patterns of sexual conduct in their Sexual Script Theory, which they used to describe socially and culturally internalized behaviors in

\footnotetext{
${ }^{11}$ Gayle Rubin, Thinking Sex: Notes for a Radical Theory of the Politics of Sexuality, in PLEASURE AND DANGER: EXPLORING Female SeXuality 267, 275 (Carol S. Vance ed., 1984).

${ }^{12}$ Jacobellis v. Ohio, 378 U.S. 184, 197 (1964) (Stewart, J., concurring).

${ }^{13}$ See Paul Gewirtz, On "I Know It When I See It," 105 Yale L.J. 1023 (1996).

${ }^{14}$ See generally Joachim Renzikowski, Defining Sexual Acts, 22 German L.J. (2021), in this special issue.

${ }^{15}$ Strafprozessordnung [STPO] [Code of Criminal Procedure], $\$ 184$, https://www.gesetze-im-internet.de/englisch_stgb/ englisch_stgb.html\#p1801 (Ger.).

${ }^{16}$ Regierungsentwurf [Cabinet Draft], Deutscher Bundestag: Drucksachen[BT]18/8556, 59 (Ger.).

${ }^{17}$ Thomas Macaulay Millar, Toward a Performance Model of Sex, in Yes Means Yes! Visions of Female SeXual Power AND A WORld Without Rape 29, 30 (Jaclyn Friedman \& Jessica Valenti eds., 2008).

${ }^{18}$ See Christine L. Hackman, Sarah E. Pember, Amanda H. Wilkerson, Wanda Burton \& Stuart L. Usdan, Slut-shaming and Victim-blaming: A Qualitative Investigation of Undergraduate Students' Perceptions of Sexual Violence, 17 SEX EDUC. 697 (2017); Aleza K. Summit, Debra Kalmuss, Jenifer DeAtley \& Andrew Levack, Unraveling the Slut Narrative: Gender Constraints on Adolescent Girls' Sexual Decision-Making, 11 AM. J. OF SEXUALITY Educ. 113 (2016).
} 
sexual interactions. ${ }^{19}$ These performances take place in a complex system of commercialization, (self-)marketing, and objectification of sexualities. From a feminist perspective, they are embedded in patriarchal structures and hierarchies. Therefore, a concept for ensuring sexual autonomy as a human right has to address interdependencies of gender and sexuality in order to address particular risks to women and girls and to guarantee sexual rights without discrimination.

\section{A Perspective on the Conditions of Autonomy and Consent}

In the 1980s and 1990s, the political and social debate about sexuality became more aware of the individual and its self-determination. Research on sexuality shows that autonomy and sexual consent are increasingly shaping sexual interactions and their social recognition. ${ }^{20}$ Moreover, the focus is on whether and how consent to sexual activity is achieved. Focusing on the process of negotiation leads to flexibility, as it is not sexual activities but the communication about them that is evaluated. However, sexual communication is complex, and-depending on the interpersonal situation and the social context-people's ability to express (un)willingness to sexual interaction may be impaired. Furthermore, sexual negotiation is characterized by a "notorious gender gap in sexual communication." 21

This does not regard the legal term of consent, but the process of interaction with ongoing negotiation. In this respect, the concept of sexual consent is about more than a yes or no. ${ }^{22}$ Elisabeth Holzleithner vividly describes the framework of negotiation as a continuum between two poles, at one end of which is unwanted and forced sex, and at the other end of which is sex with full, enthusiastic consent. ${ }^{23}$ The perspective on this continuum of negotiation between the participants allows at the same time to ask what the state can and must do to protect people against sexual violence and to ensure fundamental conditions for self-determined behavior.

Following this view, a model of consent has many requirements. It depends on five conditions: Consent is achieved when (1) actors who are capable of communicating and understanding (2) meet at eye level; (3) reach an agreement on sexual action through negotiation while maintaining each person's autonomy; (4) while acting in accordance with this agreement; (5) and ensuring continuity of consent in terms of time. ${ }^{24}$ These conditions address personal, interpersonal, and structural levels and require government action at all of them. Not only are consent models criticized for being too demanding, but also for stabilizing heteronormativity and a "gendered giver-receiver grammar." ${ }^{25}$ Feminist scholar Catharine A. MacKinnon offers a major critique of "the vicissitudes of consent" by describing consent models as redefining rape: "Voilà: consent to sex, a/k/a acquiescence to power."26

However, the idea of consent also promises a lot. In a relational turn, it can be used to describe multiple state obligations including information and education, access to medical services, and overcoming stereotypes. This offers great potential for a human rights debate concerning sexual

\footnotetext{
${ }^{19}$ John H. Gagnon \& William Simon, Sexual Conduct (1973).

${ }^{20}$ Helga Krüger-Kirn, Sexuelle Freiheit im Spannungsfeld von Heteronormativität und Heterogenität, in FEMINISMUS UND

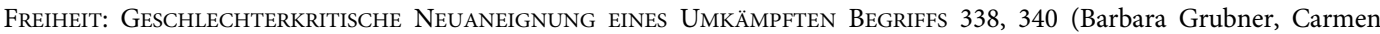
Birkle \& Annette Henninger eds., 2016); Sophinette Becker, Sexuelle Verhältnisse im gesellschaftlichen Wandel, in SozIALE Dimensionen der Sexualität 177, 187 (Thorsten Benkel \& Fehmi Akalin eds., 2010).

${ }^{21}$ Stephen J. SchulHofer, UnWANTEd SEX 256 (1998).

${ }^{22}$ Stephen J. Schulhofer, Consent: What It Means and Why Time to Require It, 47 The U. PAC. L. REV. 665, 667.

${ }^{23}$ Elisabeth Holzleithner, Sexuelle Selbstbestimmung als Individualrecht und als Rechtsgut, in REGULIERUNGEN DES INTIMEN: SeXualität und Recht Im Modernen StaAt 31, 39 (Ulrike Lembke ed., 2017).

${ }^{24}$ See Dana-Sophia Valentiner, Das Grundrecht auf SeXuelle Autonomie: Zugleich eine

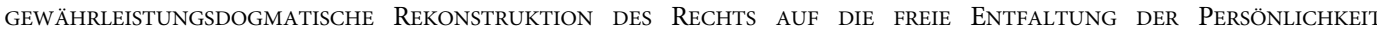
(forthcoming 2021).

${ }^{25}$ See generally Rona Torenz, The Politics of Affirmative Consent, 22 GERMAN L.J. (2021), in this special issue.

${ }^{26}$ Catharine A. MacKinnon, Rape Redefined, 10 HARV. L. \& POL'Y REV. 431, 441 (2016).
} 
autonomy. And here I do not share the concern outlined by MacKinnon, because the point of a communicative model of consent is not to distinguish punitive from non-punitive behavior, but to ask what states have to do to secure basic conditions for autonomy and consent.

\section{B. Sexual Rights in Human Rights Law}

Only a few human rights documents in European and international law explicitly state sexual rights. Sexual autonomy is guaranteed in interaction of protecting privacy and sexual health as well as the principle of anti-discrimination. In the following paragraphs, I will explore how these different aspects contribute to sexual autonomy. Therefore, it is necessary to take a closer look at the jurisprudence of the European Court of Human Rights (ECtHR), certain human rights treaties, and soft law instruments.

\section{ECtHR's Case Law on Privacy}

Article 8 of the European Convention on Human Rights (ECHR) states that everyone has the right to respect for his or her private and family life, home, and correspondence. Sexual autonomy is not mentioned in the convention. Nevertheless, according to the ECtHR, it is guaranteed by the right to privacy because "sexual life is part of private life." 27 Since the 1970s, the Court stressed this in several decisions, especially in the context of criminal laws on so-called "homosexual acts" (consensual sexual activities between adults of the same- namely male-sex). ${ }^{28}$ Furthermore, the Court has repeatedly held that sexual life as well as sexual orientation and gender identity fall within the scope of Article 8 (1) ECHR. ${ }^{29}$ This broad range developed by the Court leads to the understanding that respect for private life does not only include privacy protection but also a right to personal autonomy and development. More than a right to respect, Art. 8 (1) ECHR also contains positive obligations of the State Parties to protect private life from interferences by third parties and to fulfill basic conditions for autonomy. This includes protection from sexual violence and prevention through education.

\section{Respect for Private Life: A Right to Personal Autonomy}

The term "private life" implies a certain separation of public and private spheres, which may from a feminist perspective conflict with the protection of sexual autonomy. ${ }^{30}$ However, the ECtHR interprets the concept of private life broadly and not limited to home and living space. Privacy is guaranteed in public as well. The scope of protection in public may diminish-at least when individuals act publicly in a way they can no longer expect to be covered by the protection of

\footnotetext{
${ }^{27}$ See Brüggemann and Scheuten v. Germany, App. No. 6959/75 (May 19, 1976), http://hudoc.echr.coe.int/eng?i=00174824; Dudgeon v. The United Kingdom, App. No. 7525/76, para. 41 (Oct. 22, 1981), http://hudoc.echr.coe.int/eng?i= 001-57473; Norris v. Ireland, App. No. 10581/83, paras. 36, 46 (Oct. 26, 1988), http://hudoc.echr.coe.int/fre?i=001-57547; Modinos v. Cyprus, App. No. 15070/89, para. 24 (Apr. 22, 1993), http://hudoc.echr.coe.int/eng?i=001-57834; Smith and Grady v. The United Kingdom, App. No. 33985/96, 33986/96, para. 86 (Sep. 27, 1999), http://hudoc.echr.coe.int/ eng?i=001-58408; A.D.T. v. The United Kingdom, App. No. 35765/97, para. 26 (Jul. 31, 2000), http://hudoc.echr.coe.int/ eng?i=001-58922; L. and V. v. Austria, App. No. 39392/98, 39829/98, para. 36 (Jan. 9, 2003), http://hudoc.echr.coe.int/eng?i=001-60876.

${ }^{28}$ Dudgeon, App. No. 7525/76 at para. 41; Norris, App. No. 10581/83 at paras. 36, 46; Modinos, App. No. 15070/89 at para. 24; Smith and Grady, App. No. $33985 / 96$ at para. 86; L. and V., App. No. 39392/98 at para. 36.

${ }^{29}$ Goodwin v. The United Kingdom, App. No. 28957/95, para. 90 (Jul. 11, 2002), http://hudoc.echr.coe.int/eng?i=00160596; I. v. The United Kingdom, App. No. 25680/94, para. 70 (Jul. 11, 2002), http://hudoc.echr.coe.int/eng?i=001-60595; Van Kück v. Germany, App. No. 35968/97, paras. 69, 73 (Jun. 12, 2003), http://hudoc.echr.coe.int/eng?i=001-61142.

${ }^{30}$ Chrisje Brants, The State and the Nation's Bedrooms, in Personal Autonomy, the Private Sphere and Criminal Law: A Comparative STUdy 117, 131 (Peter Alldridge \& Chrisje Brants eds., 2001) (“To consider the right to sexual autonomy as part of the right to privacy means that some forms of sexual expression may be construed as a threat to public health or morals and implies and perpetuates distinctions between acceptable and non-acceptable sexuality.").
} 
privacy. The ECtHR applies a "reasonable expectation of privacy" test to set the limits. According to this test, the relevant aspect falls within the scope of the Convention if a person can reasonably expect to be protected in public with respect to privacy. Through the test, the ECtHR adopts a balancing perspective focusing on the social context of personal autonomy. This raises the question of how non-discrimination towards minorities can be considered when using the test. The Court clarifies Article 8 does not only cover the "inner circle' in which the individual may live his own personal life as he chooses and to exclude therefrom entirely the outside world not encompassed within that circle," but a right to establish and develop relationships with other people. ${ }^{31}$ The ECtHR has developed the right under Article 8 towards autonomy based on a concept of personal autonomy. The Court has stated that "although no previous case has established as such any right to selfdetermination as being contained in Article 8 of the Convention, the Court considers that the notion of personal autonomy is an important principle underlying the interpretation of its guarantees." 32 This broad understanding is more than just the protection of privacy. In fact, it means that every person is free to organize his or her life as he or she wants, including his or her sexual life.

\section{Consensual Sexual Activities}

In its landmark decision on the criminalization of homosexual acts, Dudgeon v. United Kingdom, the Court found a continuing violation of the applicant's right to respect for his private life, noting that "either he respects the law and refrains from engaging even in private with consenting male partners in prohibited sexual acts to which he is disposed by reason of his homosexual tendencies, or he commits such acts and thereby becomes liable to criminal prosecution." ${ }^{33}$ The ECtHR sets high standards for the justification of criminal bans as long as they concern consensual homosexual acts, especially in private spheres. ${ }^{34}$ Even though national authorities have a wide margin of appreciation with regard to legislative aims for criminal laws even on sexual activities. Furthermore, the moral climate in sexual matters could legitimately be considered justifying for the "protection of morals" mentioned in Article 8 (2) ${ }^{35}$ But the Court recognized social changes in accepting homosexuality and stated that prohibiting homosexual acts concerns an "essentially private manifestation of the human personality." 36 This may not be called into question because some people may be shocked, offended, or disturbed by homosexuality "when it is consenting adults alone who are involved." ${ }^{37}$ Following this rationale further, the protection of consensual sexual acts between adults - even between more than two adults ${ }^{38}$ — is outweighing the protection of people who feel harassed by others who are not conforming with their moral beliefs. The Court thus emphasized the special protection of privacy on the one hand and focused on sexual consent by the participants on the other.

Looking at case law, sexual consent has an explicitly doctrinal impact on the guarantee of sex. Further decisions by the ECtHR reduced the margin of appreciation held by the State Parties regarding restrictions of consensual sexuality among adults in order to protect morals. ${ }^{39}$

\footnotetext{
${ }^{31}$ Niemietz v. Germany, App. No. 13710/88, para. 29 (Dec. 16, 1992), http://hudoc.echr.coe.int/eng?i=001-57887; Amann v. Switzerland, App. No. 27798/95, para. 65 (Feb. 16, 2000), http://hudoc.echr.coe.int/eng?i=001-58497; Paradiso and Campanelli v. Italy, App. No. 25358/12; para. 159 (Jan. 24, 2017), http://hudoc.echr.coe.int/eng?i=001-170359.

${ }^{32}$ Pretty v. The United Kingdom, App. No. 2346/02, para. 61 (Apr. 29, 2002), http://hudoc.echr.coe.int/eng?i=001-60448; Van Kück, App. No. 35968/97 at para. 69.

${ }^{33}$ Dudgeon, App. No. $7525 / 76$ at para. 41.

${ }^{34} \mathrm{Id}$. at paras. 49,55 .

${ }^{35} \mathrm{Id}$. at paras. $59-60$.

${ }^{36} I d$. at para. 60 .

${ }^{37} I d$. at para. 41 .

${ }^{38}$ See generally A.D.T., App. No. $35765 / 97$ at paras. 26, 36.

${ }^{39}$ Norris, App. No. 10581/83. Modinos, App. No. 15070/89. Concerning the exclusion of homosexual persons from military service see Smith and Grady, App. No. 33985/96 and Lustig-Prean and Beckett v. The United Kingdom, App. No. 31417/96, 32377/96, (Sep. 27, 1999), http://hudoc.echr.coe.int/eng?i=001-58407.
} 
In Laskey and Others $v$. The United Kingdom, the ECtHR found that criminal laws penalizing consensual sexual acts in private may, however, be justified in certain constellations in order to protect bodily integrity. ${ }^{40}$ The three applicants were prosecuted because of sexual offenses concerning the infliction of genital injuries, beatings, and the branding of themselves and other consenting participants at private sadomasochism sex parties. The Court concluded that "not every sexual activity carried out behind closed doors necessarily falls within the scope of Article $8 . " 41$ It held that the government was entitled to adopt measures under criminal law to protect people's bodily integrity. In this context, the ECtHR distinguished between consensual sexual acts and torture-like acts of violence where consent could no longer be given. ${ }^{42}$ While the decision was probably based on stereotypes about legitimate sexual practices-not including BDSM (Bondage \& Discipline, Domination \& Submission, Sadism \& Masochism), especially not between gay men-it addressed the importance of consent in national criminal law. However, the Court granted the State Parties a wide margin of appreciation: "The whole issue of the role of consent in the criminal law is of great complexity and the Contracting States should enjoy a wide margin of appreciation to consider all the public-policy options." ${ }^{43}$

The aforementioned judgments clearly show that consensual sexual acts are protected by the right to respect for private life under Article 8 (1) ECHR. Interferences in one's "sexual life" can only be justified if there are weighty reasons for them. ${ }^{44}$ The protection of bodily integrity in case of violence could be seen as a serious reason. Yet, there are high requirements for the justification for interfering with non-violent, consensual sexual acts between adults. In the ECtHR's case law, the broad margin of appreciation of the State Parties in limiting Article 8 (1) ECHR to the "protection of morals" decreases.

\section{The Duty to Protect Sexual Autonomy Through Criminal Law}

In order to ensure respect for private life, positive obligations of the State Parties can be derived from Article 8-in conjunction with the prohibition of inhuman or degrading treatment or punishment in Article 3. The states are obliged to refrain from any interference with private life. In addition, Article 8 entails duties to protect all citizens, especially from violence. ${ }^{45}$ This may require criminal measures to secure sexual autonomy.

The ECtHR ruled in $X$ and $Y v$. The Netherlands that Dutch criminal law-by not adequately protecting mentally disabled persons from sexual abuse because they could not file a criminal complaint required to prosecute sexual offenses - did not meet the requirements of the duties to protect under Article $8 .{ }^{46}$ Sexual offences generally violate fundamental values and the inner circle of private life. Therefore, effective deterrence through sufficient criminal law provisions is crucial. In M.C. v. Bulgaria, the ECtHR derived positive obligations of State Parties from Article 3 and Article 8 to enact criminal laws regarding rape and implement them through effective prosecution. ${ }^{47}$ The ECtHR pointed out that further development of national criminal law on sexual offenses had taken place in many Convention States. For rape, the use of physical violence to overcome the victim-survivor's resistance is no longer compulsory. The offense of rape is also

\footnotetext{
${ }^{40}$ Laskey and Others v. The United Kingdom, App. No. 21627/93, 21628/93, 21974/93 (Feb. 19, 1997), http://hudoc.echr. coe.int/eng?i=001-58021.

${ }^{41} I d$. at para. 36.

${ }^{42} I$. at paras. $39-40$.

${ }^{43} \mathrm{Id}$. at para. 40 .

${ }^{44}$ Stübing v. Germany, App. No. 43547/08, para. 59 (Apr. 12, 2012), http://hudoc.echr.coe.int/eng?i=001-110314. See also Dudgeon, App. No. 7525/76 at para. 52; Norris, App. No. 10581/83 at para. 46.

${ }^{45} \mathrm{X}$ and Y v. The Netherlands, App. No. 8978/80, para. 23 (Mar. 26, 1985), http://hudoc.echr.coe.int/eng?i=001-57603; Airey v. Ireland, App. No. 6289/73, para. 32 (Oct. 9, 1979), http://hudoc.echr.coe.int/eng?i=001-57420; M.C. v. Bulgaria, App. No. 39272/98, para. 150 (Dec. 4, 2003), http://hudoc.echr.coe.int/eng?i=001-61521.

${ }^{46} X$ and $Y$, App. No. $8978 / 80$ at para. 27.

${ }^{47}$ M.C., App. No. $39272 / 98$ at para. 153.
} 
realized when consent is lacking. ${ }^{48}$ This development reflects societal change towards gender equality and respect for each individual's sexual autonomy. ${ }^{49}$ In M.C. v. Bulgaria, the Bulgarian prosecution authorities had trivialized a rape concerning a minor as "date rape," because the victim-survivor did not resist in any physical way. ${ }^{50}$ Solely due to this lack of resistance, the authorities did not pursue criminal prosecution. According to the ECtHR, this was far from effective prosecution of non-consensual sexual acts and thus a violation of the positive obligations under Article 3 and Article 8.

In support of this case law, in I.G. v. Moldova, the Court strongly condemned the lack of adequate protection of sexual autonomy in prosecutions for the rape of a 14-year-old girl in Moldova. ${ }^{51}$ The prosecution authorities and the national courts had failed to properly verify whether consent had been lacking. In D.J. v. Croatia, the Court further concluded that State Parties violate their positive obligation to effectively prosecute rape and abuse when the police fail to secure necessary forensic materials and neglect to conduct proper interviews with prospective witnesses. ${ }^{52}$ In this case, no forensic examination of the skirt worn by the complainant during the reported incident was conducted-even after multiple requests. According to the Court, even a defendant's claim that the rape victim-survivor was under the influence of alcohol or allegations about her behavior or personality do not relieve national authorities of their duty to carry out a proper investigation. ${ }^{53}$ Furthermore, in Söderman v. Sweden, the ECtHR considered the state's duty to protect to be violated when a man was not punished under Swedish criminal law for secretly filming his 14-year-old stepdaughter while she was showering for sexual purposes. It was neither classified as sexual harassment because there was no intention of the filmmaker to let the victim-survivor become aware of the films, nor as attempted child pornography, because the recordings were not pornographic. ${ }^{54}$ There were no civil law options for prosecuting the victim-survivor's injury either. So, the Swedish law did not sufficiently guarantee the integrity of the complainant, which meant that the state violated its positive obligations under Article 8. The ECtHR also ruled in cases of domestic violence that the State Parties are obliged under Article 3-in conjunction with the prohibition of discrimination in Article 14-to ensure effective prosecution to protect victim-survivors, especially from sexual violence. ${ }^{55}$

Overall, the case law shows that the State Parties are obliged to ensure effective protection against sexual offenses. The ECtHR is sharpening the duty to protect with regard to profound violations such as rape and sexual abuse as well as domestic violence into a duty to prosecute and to punish these violations primarily through criminal law. According to the ECtHR, criminal law must provide sufficient protection against non-consensual sexual acts and therefore cannot reduce sexual abuse and rape to cases in which the victim-survivor physically resists an attack. For its extensive approach, the ECtHR's case law is considered to be "the most effective [international human rights law mechanism] in securing justice for rape victims." 56 For the conception of the human right to sexual autonomy, it is crucial that the Court highlights sexual violence as damaging the individual's personal autonomy.

\footnotetext{
${ }^{48} I d$. at paras. $164-166$.

${ }^{49} \mathrm{Id}$. at para. 165 .

${ }^{50} I d$. at para. 179.

${ }^{51}$ I.G. v. Moldova, App. No. 53519/07, para. 42 (May 15, 2012), http://hudoc.echr.coe.int/eng?i=001-110904.

${ }^{52}$ D.J. v. Croatia, App. No. 42418/10, para. 94 (Jul. 24, 2012), http://hudoc.echr.coe.int/eng?i=001-112321.

${ }^{53}$ Id. at para. 101 .

${ }^{54}$ Söderman v. Sweden, App. No. 5786/08, para. 92-94 (Nov. 12, 2013), http://hudoc.echr.coe.int/eng?i=001-128043.

${ }^{55}$ Mudric v. The Republic of Moldova, App. No. 74839/19, para. 47 (Jul. 16, 2013), http://hudoc.echr.coe.int/eng?i=001122375; Eremia v. The Republic of Moldova, App. No. 3564/11, para 56 (May 28, 2013), http://hudoc.echr.coe.int/eng?i=001119968. See also Opuz v. Turkey, App. No. 33401/02, para. 160 (Jul. 9, 2009), http://hudoc.echr.coe.int/eng?i=001-92945.

${ }^{56}$ Ivana Radičić, The European Court of Human Rights as a Mechanism of Justice for Rape Victims: Contributions and Limitations, in Rape Justice: Beyond the Criminal Law 127, 128 (Anastasia Powell, Nicola Henry \& Asher Flynn eds., 2015).
} 


\section{Sex Education}

In several cases, the ECtHR dealt with sex education in schools and examined whether national school laws were compatible with Article 2 of the First Protocol to the ECHR. Article 2 (1) of the First Protocol guarantees a - negatively worded - right to education ("No person shall be denied the right to education"). Article 2 (2) additionally clarifies that the state, in the exercise of its educational responsibilities, shall respect the right of parents to ensure such education and teaching in conformity with their own religious and philosophical convictions. The ECtHR interpreted the First Protocol in light of the Convention rights, including Article 8 (1).

Back in Kjeldsen, Busk Madsen and Pedersen v. Denmark, the ECtHR held that the state is obliged to pass on information or knowledge that is part of the curriculum in a factual, critical, and pluralistic manner. ${ }^{57}$ The states have a wide margin of appreciation in designing their educational programs. Nevertheless, it is forbidden to "pursue an aim of indoctrination that might be considered as not respecting parents' religious and philosophical convictions." 58 The sex education program in Danish elementary schools did not constitute a violation of the First Protocol to the ECHR or of the Convention rights. In the view of the Court, the underlying legislation did not seek to glorify sexuality, nor to cause students to adopt prematurely behaviors that are dangerous to their mental balance, health and future, or reprehensible in the eyes of many parents. ${ }^{59}$ Moreover, the law did not affect the right of parents to educate and advise their children, to exercise their natural right to educate them, and to guide them in a manner consistent with their own religious and philosophical convictions.

In Dojan and Others v. Germany, the ECtHR upheld its decision and emphasized that sex education in schools does not violate any Convention rights if - as in the relevant case - it is limited to the neutral transfer of knowledge regarding reproduction, contraception, pregnancy and childbirth, and is taught according to modern scientific and pedagogical standards aligning with the "principles of pluralism and objectivity." ${ }^{60}$ The state's school regulations promoted a comprehensive sex education curriculum, teaching the biological, ethical, social and cultural aspects of sexuality with the aim of tolerance of all sexual orientations and gender identities, and the aim of prevention from sexual violence. According to the ECtHR, these aims were compatible with the Convention. The Court also noted that the Convention does not guarantee any right not to be confronted with opinions even if they may be in conflict with personal convictions.

In another case declared inadmissible by the ECtHR, the Court gave a detailed reasoning for approving sex education in schools at primary level. ${ }^{61}$ The importance of the social dimension for the child's personal development concerning sexuality was recognized by the Court. According to the ECtHR, children are facing many influences and are exposed to different information, in particular from the media. This kind of exposure may raise serious questions that should be discussed in school. ${ }^{62}$ The respect for parental education rights laid down in Article 5 of the Convention on the Rights of the Child (CRC) shall be focused on the well-being of the child, not the parents' moral concepts. ${ }^{63}$ The Court's findings are based on a concept of sex education that includes self-empowerment and basic knowledge in matters of sexuality. The ECtHR is focusing on promoting and accompanying the development of children. Providing education with diversified content is a precondition for sexually autonomous decision-making and acting. This does not only

\footnotetext{
${ }^{57}$ Kjeldsen, Busk Madsen and Pedersen v. Denmark, App. No. 5095/71, 5920/72, 5926/72, para. 53 (Dec. 7, 1976), http:// hudoc.echr.coe.int/eng?i=001-57509.

${ }^{58} I d$.

${ }^{59} I d$. at para. 54 .

${ }^{60}$ Dojan and Others v. Germany, App. No. 319/08, 2455/08, 7908/10, 8152/10, 8155/10, para. 2, 3 (Sep. 13, 2011), http:// hudoc.echr.coe.int/eng?i=001-106382.

${ }^{61}$ A.R. and L.R. v. Switzerland, App. No. 22338/15, para. 35 (Dec. 19, 2017), http://hudoc.echr.coe.int/fre?i=001-180402.

${ }^{62} \mathrm{Id}$.

${ }^{63} I d$. at para. 41 .
} 
apply to sex education in schools, but to every public educational service-for example, public advisory centers on pregnancy, contraception, and sexuality.

\section{Sexual and Reproductive Health in Human Rights Treaties}

In European and international law, questions of sexual autonomy are closely linked to those of reproductive and sexual health. Protection of health in this very specific form of sexual and reproductive health is guaranteed in most of the relevant human rights treaties by obliging State Parties to ensure access to basic medical services in the field of contraception, pregnancy, and sexually transmitted diseases.

Sexual and reproductive health derives from the right to health. For example, it is referred to in Article 12 of the International Covenant on Economic, Social and Cultural Rights (ICESCR), Article 12 of the Convention on the Elimination of All Forms of Discrimination against Women (CEDAW), Article 5 of the Convention on the Elimination of All Forms of Racial Discrimination (ICERD), and Article 25 of the Convention on the Rights of Persons with Disabilities (CRPD). There are General Comments or Recommendations concerning these Conventions, which are helping treaty bodies when interpreting health rights. In addition, the Declaration of Sexual Rights of the World Association for Sexual Health, a global organization concerned with sexual health and rights, contains detailed provisions on sexual health. The Declaration was originally proclaimed at the 13th World Congress of Sexology in 1997 and revised in 2014. Although it is only a non-binding statement, the Declaration shows how sexual rights can be comprehensively designed around sexual health.

\section{General Comment No. 22 (2016) on the Right to Sexual and Reproductive Health (Article 12 ICESCR)}

The right to sexual and reproductive health as expressed in Article 12 ICESCR is specified in a General Comment from 2016. ${ }^{64}$ The Comment describes the obligations of State Parties surrounding the right to sexual and reproductive health. Access to medical facilities, services, products, and information in the field of sexual and reproductive health is still limited. Inadequate health protection in the area of sexuality and reproduction is particularly harmful for people with experiences of discrimination-such as LGBTIQ* and people with disabilities. ${ }^{65}$ The General Comment clearly states that the right to sexual and reproductive health includes each person's right to make autonomous decisions regarding their own body and their sexual and reproductive health without violence, coercion, or discrimination.

Although sexual health and reproductive health are different aspects of health, they are closely linked. The Economic and Social Council defines sexual health in accordance with the World Health Organization as a "state of physical, emotional, mental and social well-being in relation to sexuality." 66 Sexual health requires availability of resources and information, as well as non-discriminatory access to contraception and medical care, including safe abortions. Reproductive health concerns the ability to reproduce and the freedom to make informed, free, and responsible choices. This shows the close link between sexual and reproductive health. Availability, information, and access to contraceptives and abortions affect reproductive health and are at the same time conditions for sexual autonomy.

The General Comment states that not only protection but also medical services must be provided by the State Parties. In addition, the General Comment explicitly considers social impacts on health. Among these are factors of social inequality, poverty, and structural discrimination, which

\footnotetext{
${ }^{64}$ ECOSOC, General comment No. 22 (2016) on the right to sexual and reproductive health (Article 12 ICESCR), UN Doc E/C.12/GC/22, https://digitallibrary.un.org/record/832961/files/E_C.12_GC_22-EN.pdf?version=1.

${ }^{65} \mathrm{Id}$. at para. 5.

${ }^{66} I d$. at para. 6.
} 
State Parties have to address. Furthermore, the synergistic effects of various human rights are emphasized as well: For example, the right to sexual and reproductive health in conjunction with the right to education and with the principle of equal rights and non-discrimination contains a right to comprehensive, non-discriminatory, and age-appropriate information on sexuality and reproduction. ${ }^{67}$ And the right to sexual health combined with the right to work under fair conditions-Articles 6 and 7 ICESCR - as well as with the right to non-discrimination and equality between men and women require State Parties to protect employees from sexual harassment in the workplace. The General Comment is therefore teaching us that our understanding of human rights needs to be seen together.

\section{General Recommendation No. 24 (1999) on Women and Health (Article 12 CEDAW)}

The General Recommendation No. 24 of the CEDAW Committee on Article 12 CEDAW deals with women's sexual and reproductive health. ${ }^{68}$ State Parties must eliminate discrimination against women regarding access to health services during their entire life. In particular, they must ensure access to and information about medical services. This includes efforts to establish procedures and hire competent medical staff to provide appropriate treatment to women who have been survivors of violence or sexual abuse.

The General Recommendation identifies social factors with a strong impact on women's health. It adopts an intersectional approach emphasizing special needs of vulnerable and disadvantaged women such as migrants, refugees, young girls and older women, sex workers, indigenous women, and women with physical or mental disabilities. State Parties are also required to take appropriate measures in order to deal with the fact that girls and women are often survivors of sexual violence and abuse, which exposes them to risks of psychological and physical harm, sexually transmitted diseases, and unwanted pregnancies. ${ }^{69}$ The General Recommendation qualifies gender-based violence as a health problem and obligates State Parties to establish legal regulations and guidelines to implement procedures for the health sector to combat gender-based violence and sexual abuse of women and girls. ${ }^{70}$ Moreover, the General Recommendation reflects the right to sexual health of women and girls in the light of existing power relations and hierarchies as well as common threats, such as sexual violence. In addition, State Parties have to ensure adolescents' rights to education concerning sexual and reproductive health through appropriately trained professionals that respect their rights to privacy and confidentiality. ${ }^{71}$ Finally, sex education should address gender equality, prevention of violence and sexually transmitted diseases, as well as reproductive and sexual rights.

\section{Declaration of Sexual Rights (World Association for Sexual Health)}

The current Declaration to the World Association for Sexual Health from 2014 lists 16 rights and freedoms enshrined in international human rights treaties also applying to the area of sexuality. ${ }^{72}$ The Declaration emphasizes the importance of sexuality as a central aspect of human life: "Sexuality is a source of pleasure and wellbeing and contributes to overall fulfillment and satisfaction ... sexual rights protect all people's rights to fulfill and express their sexuality and enjoy sexual health, with due regard for the rights of others." Therefore, sexual health requires a positive and respectful approach to sexuality and sexual relationships. The possibility "of having

\footnotetext{
${ }^{67} I d$. at para. 9.

${ }^{68}$ U.N. GAOR, 54th Sess., Supp. No. 38, General Recommendation No. 24: Women and Health from the Twentieth Session, U.N. Doc. A/54/38/Rev. 1 (1999), https://www.un.org/womenwatch/daw/cedaw/reports/21report.pdf.

${ }^{69} \mathrm{Id}$. at para. 12.

${ }^{70} \mathrm{Id}$. at para. 15 .

${ }^{71} I d$. at para. 18 .

${ }^{72}$ World Association for Sexual Health, Declaration of Sexual Rights (Mar. 2014), https://worldsexualhealth.net/wpcontent/uploads/2013/08/Declaration-of-Sexual-Rights-2014-plain-text.pdf.
} 
pleasurable and safe sexual experiences, free of coercion, discrimination and violence" should always be included. The 16 sexual rights are dedicated to link human rights to sexuality. According to No. 1, everyone is entitled to enjoy all sexual rights set forth in the Declaration without distinction of any kind such as race, ethnicity, color, sex, language, religion, political or other opinion, national or social origin, place of residence, property, birth, disability, age, nationality, marital and family status, sexual orientation, gender identity and expression, health status, economic and social situation and other status. Life, freedom, and security of the person may not be threatened, limited, or taken away for reasons related to sexuality (No. 2). In this context, the Declaration explicitly mentions the protection with regards to sexual orientation. Additionally, it contains a reference to the protection of consensual sexual behavior, thus highlighting the importance of sexual consent. No. 3 states that everyone has the right to autonomy and bodily integrity including free choice of sexual behaviors, practices, partners and relationships with due regard to the rights of others. The Declaration further contains the right to be free from torture and cruel, inhuman, or degrading treatment or punishment (No. 4) as well as the right to be free from all forms of violence and coercion (No. 5). In No. 7, the Declaration mentions health protection as basis for sexual rights and affirms the right to the highest attainable standard of health-including sexual health-with the possibility of pleasurable, satisfying, and safe sexual experiences. Furthermore, according to No. 10, everyone has the right to comprehensive sex education based on scientific evidence and grounded in human rights, gender equality, and a positive approach to sexuality and pleasure. Other articles guarantee free marriage and the decision whether or not to have children. It further notes that freedom of expression and assembly also apply with regard to sexuality.

The Declaration comprehensively stresses that UN human rights cover the sphere of sexuality. First and foremost, the Declaration helps to recognize sexuality as an area of life that needs to be protected by human rights in the same way as any other area of life. It clarifies that multiple conditions for sexual health must be ensured by State Parties for full human rights protection. The Declaration therefore offers an important approach and draws attention to the problems and dangers that can arise if human rights are not consistently applied to the area of sexuality.

\section{Non-Discrimination}

Human rights treaties promote discrimination-free application of their rights. In particular, the prohibition of discrimination on the basis of sexual orientation, the duty of the States Parties to overcome gender stereotypes, and the requirement of equal sexual and reproductive rights, all together guarantee sexual autonomy. The Yogyakarta Principles excellently illustrate how State Parties can ensure non-discrimination and gender equality while implementing human rights.

\section{Gender Equality and Protection from Discrimination}

Everyone has the right to enjoy the rights and freedoms set forth in the UN human rights treaties without distinction of any kind, such as race, sex, language, religion, political or other opinion, national or social origin, property, birth or other status (Article 2 (2) ICESCR, Article 2 (1) ICCPR, Article 2 (1) CRC, Article 14 ECHR). The prohibitions on discrimination contain an open list of discrimination grounds including sexual orientation as "other status." High requirements are placed on the justification of unequal treatment on the basis of sexual orientation. The ECtHR, for example, requires "particularly serious reasons." ${ }^{\prime 3}$ The prohibitions of discrimination oblige the States Parties to refrain from direct and indirect discrimination. They also create state obligations to protect people against discrimination by third parties. State Parties shall take all

\footnotetext{
${ }^{73}$ See, e.g., Smith and Grady, App. No. 33985/96, 33986/96 at para. 90; S.L. v. Austria, App. No. 45330/99, para. 37, (Jan. 9, 2003), http://hudoc.echr.coe.int/eng?i=001-60877. See also Karner v. Austria, App. No. 40016/98, para. 37 (Jul. 24, 2003), http://hudoc.echr.coe.int/eng?i=001-61263.
} 
appropriate measures to implement the principles of equality and non-discrimination, including affirmative action to challenge existing forms of discrimination.

The conventions against discrimination on specific grounds-such as ICERD, CRPD, and CEDAW - obligate the State Parties to take measures eliminating discrimination. ICERD and CRPD contain broad prohibitions of racial discrimination and discrimination against people with disabilities. Therefore, the conventions call for measures to ensure equal treatment and to dismantle discriminatory structures and stereotyping. For instance, Article 5 (a) CEDAW obliges State Parties to take all appropriate measures to modify the social and cultural patterns of conduct of men and women with a view to achieving the elimination of prejudices and customary and all other practices which are based on the idea of the inferiority or the superiority of either of the sexes or on stereotyped roles for men and women. The states' obligation to act against stereotyping — in conjunction with Art. 2 (e) CEDAW — extends to measures against third parties.

To overcome stereotypes, State Parties are also obliged to take action regarding the prevention of violence against women and domestic violence by Article 12 of the Istanbul Convention. According to Article 13, State Parties should promote measures to raise awareness and increase consciousness of violence against women. Article 14 states that the parties shall take the necessary steps-where appropriate- to include teaching material on issues such as equality between women and men, non-stereotyped gender roles, mutual respect, non-violent conflict resolution in interpersonal relationships, gender-based violence against women, and the right to personal integrity. In Article 15, the Istanbul Convention also establishes an obligation for State Parties to provide education and training for members of certain professional groups, for example: medical professionals, police officers, state prosecutors, and judges.

Overall, CEDAW and the Istanbul Convention oblige State Parties to take measures to ensure that prosecutions for crimes against sexual autonomy are free from stereotyping. This requires challenging prevailing gender stereotypes and rape myths demeaning women, especially in rape trials.

\section{Yogyakarta Principles}

In 2006/2007, leading human rights experts drafted the Yogyakarta Principles-which were further elaborated in 2017-to ensure that human rights are applied without discrimination regarding sexual orientation and gender identity. Although the Yogyakarta Principles are not binding international law, the principles have been adopted by United Nations institutions. The Yogyakarta Principles reflect the experiences of LGBTIQ ${ }^{*}$ people and consider human rights violations for reasons of gender identity and sexual orientation. On this basis, the Document stresses out States Parties' obligations to ensure the effective implementation of human rights for all people. ${ }^{74}$ The Yogyakarta Principles were created in response to numerous killings, the ongoing torture and abuse, sexual assault and rape, invasion of privacy, and various forms of discrimination against people because of their sexual orientation or gender identity.

The Yogyakarta Principles strengthen already existing UN human rights and set out concrete measures. 38 principles include detailed recommendations for State Parties and UN institutions to realize human rights relating to sexual orientation and gender identity. The Principles adopt an intersectional approach, emphasizing that violations would often be compounded with experiences of other forms of violence, hatred, discrimination, and exclusion.

Some of these principles relate to sexual autonomy. Principle No. 2 states the right to equality and non-discrimination. It entitles everyone to enjoy all human rights without discrimination on the basis of sexual orientation or gender identity. No. 2(b) and No. 6(b) require states to change criminal laws that prohibit consensual sexual activity between people of the same sex who have

\footnotetext{
${ }^{74}$ See Valérie V. Suhr, Protection of Sexual and Gender Minorities Through International Criminal Law (forthcoming 2021) (analyzing the state of LGBTIQ* humans rights).
} 
reached the age of consent, and to ensure that people of the same sex are subject to the same age of consent as those of opposite sex. Principle No. 6 concerns the right to privacy, which encompasses the decision to disclose or not disclose information related to sexual orientation or gender identity to others. Engaging in consensual sexual acts is a part of privacy. To guarantee such privacy, states are responsible for ensuring the right to decide when, to whom, and how to disclose information about one's sexual orientation or gender identity. States must also provide adequate protection against unwanted or threatened disclosure of such information by others. Furthermore, the right to personal security requires protection from violence and assault related to sexual orientation and gender identity (Principle No. 5).

The Yogyakarta Principles thus not only recognize that all people-regardless of sexual orientation and gender identity-are entitled to equal participation in human rights protection. They also propose an inclusive interpretation of international law bringing forth tangible state obligations to respect, to protect, and to fulfill human rights. Moreover, the principles address the day-to-day reality of marginalized and disadvantaged people and propose concrete measures to enable them in leading a self-determined life.

\section{A Multidimensional Approach to the Human Right to Sexual Autonomy}

The discussion regarding sexual rights in international and European human rights law has shown that sexual autonomy can be understood as a right to privacy, but also in terms of sexual health or non-discrimination. A multidimensional approach to sexual autonomy allows one to elaborate the various states' obligations to guarantee sexual autonomy - in particular the duties to respect, to protect, and to fulfill. At the same time, a decentralized conceptual framework reflecting the principles of equality, non-discrimination, personal autonomy, and privacy enables the realization of sexual autonomy in various areas of law and pluralizes the regulatory options. ${ }^{75}$

Respect for private life is understood in the sense of guaranteeing personal autonomy, as illustrated by the case law of the ECtHR. Such a broad understanding permits handling the problematic separation of public and private spheres, because sexual life is not simply declared a private matter. Rather, the right to privacy clearly distinguishes between consensual sexuality on the one hand and sexual violence on the other. Consensual sexual acts enjoy the protection of privacy. The ECtHR sets very high standards for the justification of state interference with non-violent, consensual sexual acts between adults. Furthermore, the right to privacy also implies State Parties' duties to protect when it comes to non-consensual sexual acts. Especially as sexual violence, rape, and sexual abuse must be effectively combated. This includes prosecuting non-consensual acts even when the victim-survivor did not physically resist.

Duties to protect also guarantee competent prosecution and enforcement of criminal law. This requires information campaigns, education, and training. Moreover, the duties to protect cover the area of prevention. Here, sex education plays a crucial role. The ECtHR frames sex education as an expression of social participation and, from this perspective, derives substantive standards for its content to balance the child's rights, the parents' rights, and the state's educational missions in a supportive, empowering concept of education.

The guarantee of sexual health adds another facet to the multidimensional human right to sexual autonomy. Access to medical information and services, especially contraceptives and safe abortions, is a fundamental requirement for sexual autonomy, enabling free and self-determined decision-making about one's own sexual behavior. The obligations of the States Parties include adequate provisions to protect people from sexually transmitted diseases as well as the provision of medical abortion services. As General Comment No. 22 (2016) on the Right to Sexual and Reproductive Health shows, human rights can only be enforced by considering social factors

${ }^{75}$ See Jean L. Cohen, Regulating Intimacy: A New Legal Paradigm 176, 178 (2002). 
and implementing state measures to overcome them. Therefore, the social dimension of human rights has to be incorporated into a right to sexual autonomy.

Finally, the human right to sexual autonomy cannot be fully guaranteed without incorporating the principles of gender equality and non-discrimination. The prohibition of discrimination in international and European human rights systems ensures equal enjoyment of all rights including sexual autonomy. Non-discrimination and gender equality have to be reflected as cross-cutting issues in all facets of the multidimensional approach to sexual autonomy. For this, sex education in schools has to be aligned with these principles. Prosecution of rape and sexual abuse needs to be free of stereotyping. Access to medical services has to be available to everyone-regardless to their gender identity or sexual orientation. By human rights, states are obliged to work towards the end of discrimination. In order to adequately deal with specific risks for the individual's autonomy, an intersectional perspective is necessary. Instruments such as the Yogyakarta Principles demonstrate how an intersectional perspective can reflect specific risks for LGBTIQ ${ }^{*}$ and ensure human rights regardless to sexual orientation and gender identity.

\section{Conclusion}

In the international and European human rights system, sexual autonomy is protected in multiple ways. Privacy and personal autonomy, sexual health, gender equality, and non-discrimination complement each other to form a holistic framework to guarantee sexual autonomy. The analysis of several human rights treaties and soft law instruments, their interpretation, and legal application has revealed an approach to sexual autonomy through a human rights lens. For further elaboration of the approach, a consent model can be used - not as a legal term, but as a procedural concept to contour responsibilities and duties of states to respect, protect, and fulfill the human right to sexual autonomy.

Cite this article: Valentiner D-S (2021). The Human Right to Sexual Autonomy. German Law Journal 22, 703-717. https:// doi.org/10.1017/glj.2021.35 